\title{
Effect of combined treatment with calcitonin on bone densitometry of patients with treated hypothyroidism
}

\author{
F. J . da C. Stamato, E. C. J . Amarante, R. P. Furlanetto \\ Division of Endocrinology, Department of Medicine, Federal University of São Paulo (EPM-UNIFESP), São Paulo, SP, Brazil
}

SUMMARY - INTRODUCTION. Thyroid hormones (TH) may affect bone metabolism and turnover, inducing a loss of bone mass among hyperthyroid and in hypothyroid patients under hormone replacement treatment. Thyroid dysfunction leads to changes in the dynamics of parathyroid hormone (PTH) and calcitonin (CT) secretion.

ОвлестіVE. The objective of the study was to determine the usefulness of $C T$ as adjuvant therapy in the prevention of bone loss during the treatment of hypothyroidism.

Material and Methods. We studied 16 female patients with recently diagnosed primary hypothyroidism, divided into two groups: group G1 $(n=8)$ submitted to treatment with thyroxine ( $L$ T4), and Group $2(n=8)$ that, in addition to being treated with $L-T 4$, received a nasal CT spray. All

\section{INTRODUCTION}

Thyroid hormones (TH) affect bone metabolism and turnover, increasing the number of bone remodeling cycles, activating and increasing the number of osteoclasts and altering the relation between bone reabsorption and bone formation $2,5,24,25$. This effect induces a loss in bone mass in hyperthyroid individuals $\mathrm{s}^{2,6,8,18,20,24}$ and also among hypothyroid patients submitted to hormonal replacement therapy ${ }^{2,5,7,18,29}$.

Parathyroid hormone (PTH) is released by the parathyroid glands depending on serum calcium and its major action is to stimulate bone reabsorption through the osteoclasts ${ }^{1}$. In hypothyroidism, basal PTH and its response to hypocalcemia are higher than in normal individuals, and this exaggerated response does not normalize even after 6 months of replacement treatment with $\mathrm{TH}^{8-12,33-35}$.

Calcitonin (CT) is a hormone mainly produced by the parafollicular cells of the thyroid (C cells) and is a potent inhibitor of bone reabsorption; its secretion is stimulated by calcium. In hypothyroidism there is a lower CT reserve and its response to a hypercalcemic stimulus is significantly patients were submitted to determination of TSH, free T4, bone mineral densitometry (BMD) and total bone calcium (TBC) at the time of diagnosis, after 6 to 9 months of treatment, and after 12 months of treatment.

Results. No statistical significant differences were detected in either group between the total BMD values obtained for the femur and lumbar spine before and after treatment. However, group G1 presented a statistical significant TBC loss after 12 months of treatment compared to initial values. In contrast, no TBC loss was observed in the group treated with LT-4 in combination with CT, a fact that may suggest that CT was responsible for the lower bone reabsorption during treatment of hypothyroidism.

KEYWORDS: Calcitonin. Osteoporosis. Hypothyroidism

reduced $^{13}$, probably due to the destruction of $\mathrm{C}$ cells by the process of chronic thyroiditis. Hypothyroid patients, when starting hormonal replacement therapy, may present bone remodeling of high turnover owing to the action of TH. Mundy, in 1976 25 , showed that CT inhibits $\mathrm{TH}$-induced bone reabsorption in vitro. Since CT mainly acts by suppressing the osteoclastic activity of bone, it may be assumed that patients with osteoporosis involving a high turnover may benefit more rapidly from CT treatment than patients with less severe disorders of bone remodeling ${ }^{1,28}$.

The ain of the present study was to assess the possible loss of bone mass occurring during treatment of hypothyroidism and to clarify the probable role of calcitonin in the prevention of osteopenia and its possible use as an adjuvant in the treatment of hypothyroidism.

\section{MATERIAL AND METHODS}

Patients: We studied 20 female patients with recently diagnosed primary hypothyroidism, seen at the Endocrinology Outpatient Clinic of UNIFESP-EPM from May 1993 to August 1995. The patients were matched for age and basal thyro- 


\begin{tabular}{|c|c|c|c|c|c|}
\hline \multicolumn{2}{|c|}{ Initial } & \multicolumn{2}{|c|}{6 to 9 Months } & \multicolumn{2}{|c|}{12 Months } \\
\hline Spine & femur & spine & femur & spine & Femur \\
\hline-0.22 & 0.43 & -0.13 & 0.29 & 0.00 & 0.03 \\
\hline$(-0.86$ to 0.64$)$ & $(-0.98$ to 1.32$)$ & $(-0.95$ to 0.55$)$ & (-0.60 to 0.82$)$ & $(-0.92$ to 0.46$)$ & $(-0.68$ to 1.66$)$ \\
\hline
\end{tabular}

\begin{tabular}{|c|c|c|c|c|c|}
\hline \multicolumn{2}{|c|}{ Initial } & \multicolumn{2}{|c|}{6 to 9 Months } & \multicolumn{2}{|c|}{12 Months } \\
\hline Spine & femur & spine & femur & spine & Femur \\
\hline 0.30 & 0.12 & 0.51 & 0.03 & 0.66 & 0.27 \\
\hline$(-3.05$ to 3.33$)$ & $(-1.78$ to 2.19$)$ & $(-2.96$ to 4.06$)$ & $(-2.24$ to 1.47$)$ & (-2.68 to 3.22$)$ & $(-2.09$ to 1.68$)$ \\
\hline
\end{tabular}

tropin (TSH) and free thyroxine (T4L) concentration and divided into two groups. The patients in group G1 $(n=10)$ received L-thyroxine at the dose of 1.6 to $2.0 \mu \mathrm{g} / \mathrm{kg} / \mathrm{day}$, while the patients in group G2 $(n=10)$ received $L$-thyroxine at the same dose in combination with calcitonin nasal spray at the dose of 100 IU three times a week. The patients were submitted to determination of TSH and T4L, to bone densitometry of the lumbar spine (BMDC), of the femur (BMDf) and of the entire body (BMDt) and to determination of total bone calcium (TBC) at the beginning of the study, after 6 to 9 months and after 12 months of treatment. Four patients (two from each group) were excluded from the evaluations because of lack of compliance with treatment. All other patients continued to be euthyroid during follow-up.

Laboratory determinations: serum T4L and TSH were determined by an ultrasensitive immunofluorimetric method, using commercial Delfia kits (Pharmacia, Turku, Finland).

Bone densitometry: Bone densitometry was determined by DEXA using a LUNAR DPX-L densitometer. The results are reported as $\mathrm{g} / \mathrm{cm}^{2}$ and the z score standard deviation was used.

Statistical analysis: The Friedman test was applied to the changes obtained in BMDc, BMDf and BMDt data along time in each group. The initial and final BMDC, BMDf, BMDt, TBC and body weight values were compared by the Wilcoxon test in each group, and the Mann-Whitney test was used for comparison between groups. The level of significance was set at $=.05 \mathrm{in}$ all analyses.

\section{RESULTS}

No patients reported any complaints about complications and/or side effects caused by calcitonin. No statistical significant variation in body weight occurred in the patients of either group during the study. The initial median weight of G1 patients was $63,87 \mathrm{Kg}$ (range: 52,0 - 73,0) and the median at the end of the study was also $63,87 \mathrm{Kg}$ (range: 51,0 to 75,0 ). The initial median weight of G2 patients was $66,75 \mathrm{Kg}$ (range: 49,0 to 77,0 ) and the median at the end of the study was $64,5 \mathrm{Kg}$ (range: 49,0 to 74,0 ).

No significant differences between groups were observed with respect to the initial values of BMDC, BMDf, BMDt and TBC.

No significant differences in total, spinal or femoral BMD (reported as $\mathrm{g} / \mathrm{cm}^{2}$ and $\mathrm{z}$ score) were observed during the study period within groups. Also, no significant differences were observed between initial and final values (Tables 1 and 2 ).

Group $\mathrm{G} 1$ presented a significant loss $(\mathrm{P}<0.01)$ of total bone calcium during the study period (Table 3$)$, with significantly lower values $(p<0.02)$ at 12 months (median 815 - range 680 to $980 \mathrm{~g}$ ) compared to initial values (median 867.5 - range 713-980 g). In group G2 there was no statistical difference between the initial (median 876.5; range 626-1057 g) and end values (median 837.5; range $607-1011 \mathrm{~g}$ ) of TBC.

\section{DISCUSSION}

Osteoporosis is a highly common skeletal disorder of multifactorial etiology which mainly affects women $^{23}$ and with important effects in terms of patient morbidity and mortality. Because of the multifactorial nature of the disorder, whenever possible the association of osteopenic factors should be avoided and, depending on the cause, treatment should be combined with pro-osteogenic or antireabsorptive drugs.

Changes in thyroid function affect the osteomineral metabolism $7,15,17,28,36$, leading to changes in the dynamics of PTH and CT secretion $8,11,13$, with a direct action of $\mathrm{TH}$ on bone tissue $\mathrm{e}^{25}$ as well as potentiation of the action of PTH on bone reabsorption $^{32}$. In hypothyroid subjects, the dynamics 


\begin{tabular}{|cccc|}
\hline \multicolumn{4}{|l}{$\begin{array}{l}\text { Tabela } 3 \\
\text { patients }\end{array}$} \\
\hline Patient no & Initial & at $\mathbf{6}$ to 9 months & at $\mathbf{1 2}$ months \\
1 & 830 & 807 & 807 \\
2 & 883 & 825 & 815 \\
3 & 852 & 806 & 815 \\
4 & 713 & 713 & 680 \\
5 & 969 & 909 & 895 \\
6 & 885 & 884 & 891 \\
7 & 806 & 798 & 799 \\
8 & 980 & 971 & 969 \\
\hline
\end{tabular}

Tabela 4 - Total bone calcium (g) determined in group G2 patients

\begin{tabular}{|cccc|}
\hline Patient no & Initial & at $\mathbf{6}$ to $\mathbf{9}$ months & at $\mathbf{1 2}$ months \\
1 & 882 & 856 & 845 \\
2 & 871 & 829 & 828 \\
3 & 1011 & 950 & 957 \\
4 & 1057 & 1007 & 1011 \\
5 & 626 & 618 & 607 \\
6 & 812 & 802 & 830 \\
\hline
\end{tabular}

of PTH secretion continues to be alter ed even after 6 months of euthyroid status ${ }^{11}$, favoring the exposure of bone tissue to relatively high quantities of PTH associated with normal TH levels, with consequent greater bone reabsorption.

Calcitonin is a potent inhibitor of bone reabsorption and its partial or total deficiency may represent the loss of an important bone-protecting factor among patients, with bone tissue becoming more vulnerable to the action of hormones that stimulate its reabsorption. In hypothyroidism there is a lower calcitonin reserve, with a significantly decreased response to the hypercalcemic stimulus $^{13}$, which justifies the therapeutic use of CT in hypothyroid patients under hormonal replacement treatment.

CT is an effective therapeutic agent in various diseases characterized by accelerated bone reabsorption ${ }^{23}$. Its therapeutic use in the treatment of osteoporosis is questionable, although this pathology is frequently associated with an increase in bone reabsorption. Results obtained in patients with accel erated bone reabsorption treated with CT have shown normalization of the loss of bone mass similar to that obtained with the use of other bone reabsorption inhibitors (estrogens and bisphosphonates) ${ }^{31}$. Other reports have demonstrated an increase in bone mass in the vertebrae and long bones ${ }^{16,22,26}$, a reduced fracture rate ${ }^{19,30}$ and relief of the syndromes accompanied by bone pain ${ }^{21}$.

Even though the evaluation of our patients did

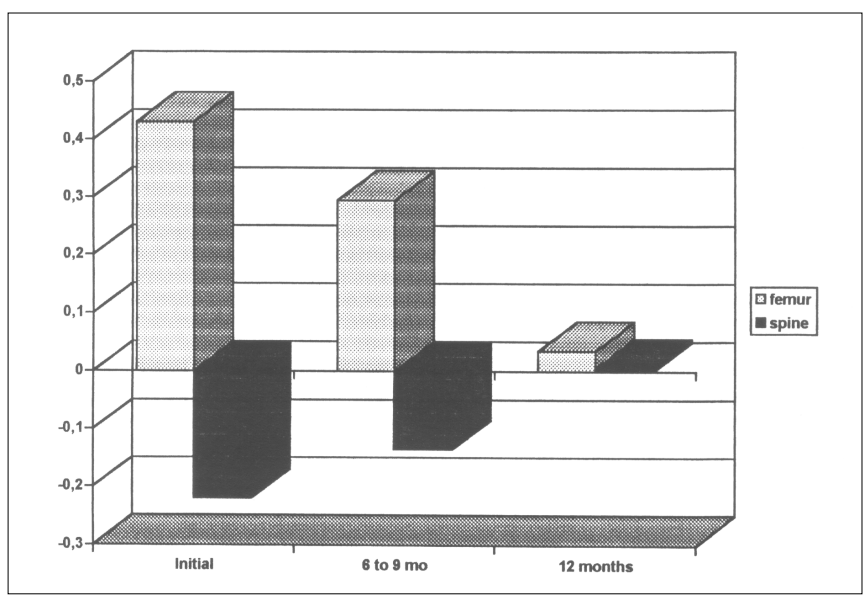

Graf. 1 - BMD (Z score) of the lumbar spine (L2-L4) and of the femural neck in group G1 (hypothyroid patients that recei ved only $L$-thyroxine)

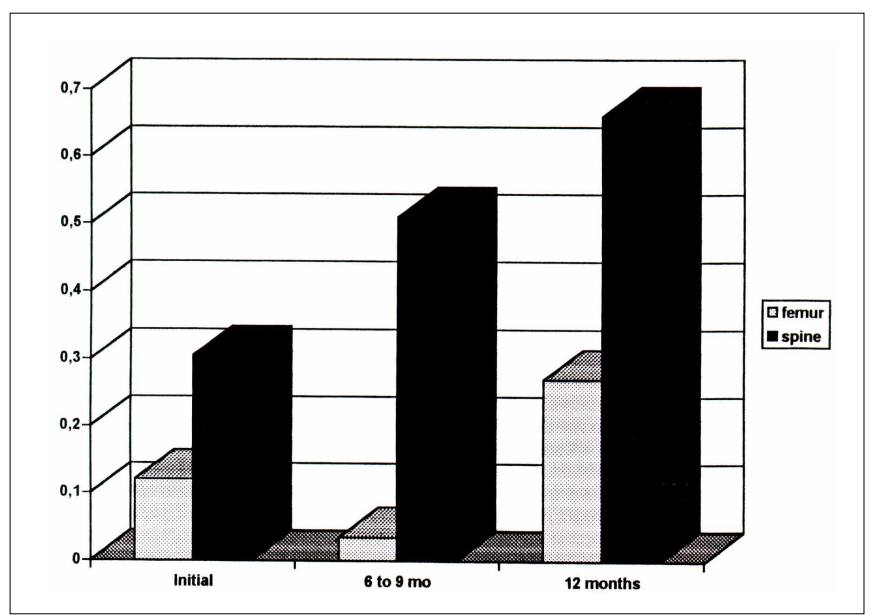

Graf. 2 - BMD (Z score) of the lumbar spine (L 2-L 4) and of the femural neck in group G2 (hypothyroid patients that received L-thyroxine in combination with calcitonin)

not reveal a significant alteration of BMDt and of lumbar spine and femur BMD, the TBC measurement showed that hypothyroid female patients presented a significant bone calcium loss after 1 year of replacement treatment with $\mathrm{TH}$ (group G1).

The combined use of CT in the treatment of hypothyroidism seems to be useful for the prevention of greater bone loss, especially in patients with other risk factors for osteopenia. This was demonstrated by the follow-up of our G2 patients treated with CT in combination with thyroid hormone, who did not show a significant TBC Ioss after 1 year of treatment.

Evaluation of TBC is considered to be the most sensitive determination for the assessment of bone mass. It is expressed in grams and may present alterations with a change in patient body 
weight. The patients in the two groups studied here did not present significant differences in weight during the study.

On the basis of these data, we may infer that a loss of bone calcium occurs in hypothyroid patients submitted to hormonal replacement, a fact that can be minimized when CT is administered in combination. Since CT is an antireabsorptive hormone, it is not expected to produce a significant increase in bone mass, but rather to maintain bone mass by the prevention or reduction of later bone losses ${ }^{23}$. It has been demonstrated that the use of CT can stabilize or modestly increase the indices of cortical and trabecular bone mass and total bone calcium when administered to patients over a period of 1 to 2 years ${ }^{23,26,27}$. Burckhardt $\&$ Burnand ${ }^{3}$ demonstrated that in all controlled studies in which CT was used there was a decrease in the rate of vertebral fractures, although the difference was not statistically significant.

As a potent antiosteoclastic drug, CT seems to be relatively harmless when compared to the potential complications caused by the other drugs used in the treatment or prevention of osteoporosis ${ }^{37}$. Among the side effects reported with the use of CT, the most important ones are nausea, gastric discomfort and skin rashes $^{1}$, which, however, were substantially reduced when the nasal spray was introduced ${ }^{4,37}$. None of the patients followed up by us complained about side effects of calcitonin.

Although our study followed the patients for one year, a more prolonged prospective study with a larger number of patients would be necessary to definitely confirm whether calcitonin is a hormone that could, or should, be added to the treatment of hypothyroidism, especially among patients with proven osteopenia.

\section{ACKNOWLEDGEMENTS}

The authors thank Dr. Marcus Magliano from Sandoz S.A. for his colaboration in Calcitonin (Miacalcic $\left.{ }^{\circledR}\right)$ supplying.

\section{RESUMO}

\section{Influência da terapêutica associada com cal- citonina sobre a densitometria óssea de pa- cientes com hipotiroidismo tratado.}

INTRODUÇÃo. Os hormônios tiroidianos (HT) podem influenciar o metabolismo e o "turnover" ósseo, induzindo perda de massa óssea em hipertiróideos e em hi póti roi deos na vigência de reposição hormonal. As disfunções ti roidianas levam a alterações na dinâmica de secreção de parator- mônio (PTH) e de calcitonina (CT).

Objetivo. Esclarecer a utilidade da CT como terapêutica coadjuvante na prevenção de perda óssea durante o tratamento do hipotiroidismo.

Material e Métodos. Dezeseis pacientes do sexo feminino com hipotiroidismo primário recémdiagnosticados, divididos em dois grupos: grupo G1 $(n=8)$ tratado com tiroxina (L-T 4) e grupo G2 $(n=8)$ que recebeu, al ém de L-T4, CT "spray" nasal. Todos os pacientes foram avaliados com TSH, T4 livre, densitometria mineral óssea (BMD) e cálcio ósseo total (TBC) ao diagnóstico após 6 a 9 meses de terapêutica e com 12 meses de tratamento.

RESULTADOS. Em ambos os grupos não foram encontradas mudanças estatisticamente significantes entre as medidas da BMD total antes eapós o tratamento, assim como no fêmur e na coluna Iombar. Entretanto, o grupo G1 apresentou perda significante do TBC após 12 meses de tratamento em relação aos valores iniciais. J á no grupo que usou terapêutica associada com CT, não houve perda de cál ci o ósseo total, o que pode sugerir que a CT foi responsável por uma menor reabsorção óssea durante o tratamento do hipotiroidismo. [Rev Ass Med Bras 2000; 46(2): 177-81]

\section{NOTICE}

The authors hereby confirm that neither the manuscript nor any part of it has been published or is being considered for publication el sewhere. By signing this letter each of us acknowledges that he or she participated sufficiently in the work to take public responsibility for its content.

\section{REFERÊNCIAS BIBLIOGRÁFICAS}

1. Avioli, L.V. - Calcitonin therapy in osteoporotic syndromes. Rheum Dis Clin North Am 20:777-785,1994.

2. Baran, D.T. \& Braverman, L.E. Editorial: Thyroid hormones and bone mass. J Clin Endocrinol Metab 72:1182-3,1991.

3. Burckhardt, P. \& Burnand, B. - The effect of treatment with calcitonin on vertebral fracture rate in osteoporosis. Osteoporos Int 3(1):24-30,1993.

4. Carstens, J.H. J r.; Feinblatt, J.D. - Future horizons for calcitonin: a US perspective. Calcif Tissue Int 49:S2,1991.

5. Coindre, J .M.; David, J .P.; Rivière, L.; Goussot, J .F.; Roger, P.; Mascarel, A.; Meunier, J .P. - Boneloss in hypothyroidism with hormone replacement.: A histomorphometric study. Arch Intern Med 146:48-53,1986.

6. Diamond, T.; Nery, L.; Hales, I. - A therapeutic dilemma: supressive doses of thyroxine significantly reduce bone mineral measurements in both premenopausal and postmenopausal women with thyroid carcinoma. J Clin Endocrinol Metab 72:1184-8,1991.

7. Franklyn, J .A.; Betteridge, J .; Daykin, J .; Holder, R.; Oates, G.D.; Parle, J .V.; et al. - Long-term thyroxine treatment and bone mineral density. Lancet 340:9-13,1992.

8. Furlanetto, R.P.; Vieira, J.G.H.; Castro, M.L.; Kasamatsu, T.S.; Mesquita, C.H.; Chacra, A.R. - Dinâmi ca da resposta do PTH à hipocalcemia induzida por EDTA no hiper e hipoti- 
roidismo. In: Congresso Brasileiro de Endocrinol ogia e Metabologia, 18, RiodeJ aneiro,1988, Resumo dos trabalhos. Riode J aneiro,1988, p.97 (Resumo, 225).

9. Furlanetto, R.P.; Castro, M.L.; Mesquita, C.H.; Kasamatsu, T.S.; Vieira, J.G.H. - Resposta do paratormônio à hipocalcemia em pacientes com disfunções tiroidianas. In: Encontro Brasileiro de Tiróide, 3, Rio de J aneiro,1989,p.18 (Resumo, T18).

10. Furlanetto, R.P.; Castro, M.L.; Kasamatsu, T.S.; Brandão, C.M.A.; Vieira, J.G.H. - Parathyroid glands hyperresponsiveness to EDT induced hypocalcemia in treated hypothyroid patients. In: Congresso Panamericano de Endocrinologia 12, Recife,1990. Endocrino 90. Recife,1990,p.113 (Resumo, 202).

11. Furlanetto, R.P.; Castro, M.L.; Kasamatsu, T.S.; Brandão, C.M.A.; Vieira, J .G.H. - Persistent hyperactivity of the parathyroid glands in treated hypothyroid patients. Acta Endocrinol (Copenh) 123:609-12,1990.

12. Furlanetto, R.P.; Castro, M.L.; Kasamatsu, T.S.; Brandão, C.M.A.; Vieira, J .G.H. - Parathyroid glands hyperresponsiveness to EDTA-induced hypocalcemia in treated hypothyroid patients. In: I nternational Thyroid Conference,10, Haia,1991, Abstract book. Haia,1991,p.169 (Abstract 278).

13. Furlanetto, R.P.; Brandão, C.M.A.; Kasamatsu, T.S.; Castro, M.L.; Vieira, J .G.H. - Calcitonin secretion in hypo and hyperthyroidism. In: Latin-American Thyroid Congress,5, São Paulo,1991, Abstract book. SãoPaulo,1991,p.21 (Abstract 38).

14. Furlanetto, R.P.; Castro, M.L.; Mesquita, C.H.; Kasamatsu, T.S.; Vieira, J.G.H. - Função paratiroidiana no hipertiroidismo: implicações no metabolismo ósseo e efeito do tratamento. Rev Paul Med 109:55-60,1991.

15. Gam, A.N.; J ensen, J .F.; Hasselstrom, K., Olsen, M.; Nielsen, K.S. - Effect of thyroxine therapy on bone metabolism in substituted hypothyroid patients with normal or suppressed levels of TSH. J Endocrinol Invest 14:451-5,1991.

16. Gennari, C.; Chierichetti, S.M.; Bigazzi, S.; et al. - Comparative effects on bone mineral content of calcium and calcium plus salmon calcitonin given in two differents regimens in postmenopausal osteoporosis. Current Therapeutic Research 38:455, 1985.

17. Greenspan, S.L.; Greenspan, F.S.; Resnick, N.M.; Block, J .E.; Friedlander, A.L.; Genant, H.K. - Skel etal integrity in premenopausal and postmenopausal women receiving long-term Ithyroxine therapy. Am J Med 91:5-14,1991.

18. Harvey,R.D.; MCHardy,K.C.; Reid,I.W.; Paterson, F.; Bewsher,P.D.; Duncan,A; Robins,S.P. - Measurements of bone collagen degradation in hyperthyroidism and during thyroxine replacement therapy using pyridiun cross-links as a specific urinary markers. J Clin Endocrinol Metab 72:1189-94,1991.

19. Kanis, J.A.; J ohnell, O.; Gullberg, B. et al. - Evidence for efficacy of drugs affecting bone metabolism in preventing hip fracture. BMJ 305:1124,1992.

20. Kroelner, B.; J orgensen, J.V.; Nielsen, S.P. - Spinal bone mineral content in myxoedema and thyrotoxicosis. Effect of thyroid hormone (s) and antithyroid treatment. Clin Endocrinol (Oxf) 18:439-46,1983.

21. Lyrits, G.P.; Tsakalakos, S.; Magiasis, B. et al. - Analgesic effect of salmon cal citonin in osteoporotic vertebral fractures: Doubleblind placebo-controlled study. Calcif Tissue Int 49: 369,1991.

22. Mazzuoli, G.F.; Passeri, M.; Gennari, C.; et al. - Effects of salmon calcitonin in postmenopausal osteoporosis: A controlled double-blind clinical study. Calcif Tissuel nt 38:3,1986.

23. McDermott, M.T.\& Kidd, G.S. - The role of calcitonin in the development and treatment of osteoporosis. Endocrine Reviews 8(4):377-384,1987.

24. Mosekilde, L.; Eriksen, E.F.; Charles, P. - Effects of thyroid hormones on boneand mineral metabolism. Endocrinol Metab Clin North Am 19:35-63,1990.

25. Mundy, C.R.; Shapiro, J.L.; Bandelin, J .G.; Canalis,E.M.; Raisz,L.C. - Direct stimulation of bone resorption by thyroid hormones. J Clin Invest 58:529-34,1976.

26. Overgaard, K.; Riis, B.J .; Christiansen, C. et al. Nasal calcitonin for treatment of established osteoporosis. Clin Endocrinol 30:435-442,1989.

27. Overgaard, K.; Riis, B.J .; Christiansen, C. et al. - Effect of salcatonin given intranasally on early postmenopausal bone Ioss. BMJ 299:477,1989.

28. Paul, T.L.; Kerrigan, J .; Kelly, A.M. et al. - Long-term Ithyroxine therapy is associated with decreased hip bone density in premenopausal women. J AMA 259:3137,1988.

29. Perry III , H.M. - Thyroid replacement and osteoporosis. Arch Intern Med 146:41-2,1986.

30. Rico, H..; Hernandez, E.R.; Diaz-Mediavilla, J .; et al. - Treatment of multiple myeloma with nasal spray calcitonin: A histomorphometric and biochemical study. BoneMiner 8:231, 1990.

31. Sambrook, P.; Birmingham, J .; Kelly, P.; et al. - Prevention of corticosteroid osteoporosis: A comparision of calcium, calcitriol, and calcitonin. N Engl J Med 328:1747,1993.

32. Schimin, E.M.K.; Steiner, T.H.; Froesch, E.R. - Triiodothyronine increases responsiveness of cultured rat bone cells to parathyroid hormone. Acta Endocrinol 11:213-6, 1986.

33. Vieira, J.G.H.; Castro, M.L.; Furlanetto, R.P.; Kasamatsu,T.S.; Mesquita, C.H.; Chacra, A.R. - Dynamics of the PTH response to EDTA induced hypocalcemia in hypo and hyperthyroidism. In: Laurence and Dorothy Fallis International Symposium,1988, Clin Bone Min Metab Detroit,1988,p.29 (abstract 74).

34. Vieira, J .G.H. \& Furlanetto, R.P. - Dynamics of the parathyroid hormone (PTH) secretion in hypo and hyperthyroidism. In: Meirelles,R.M.R.; Machado, A.; Póvoa, L.A. - Clinical Endocrinol ogy, 1 ed, Amsterdan, Excerpta Medica, 1988, p.253-5.

35. Vieira, J .G.H.; Kasamatsu,T.S.; Mesquita, C.H; Furlanetto, R.P. - parathyroid hormone response to EDTA induced hypocalcemia in hypo and hyperthyroid patients pre and posttreatment. In: International Conference on Calcium Regulating Hormones, 10, Montreal,1989, J Bone Min Res Montreal,1988, p.S157 (Abstract 158).

36. Wenzel, K.W. - Bone minerals and levothyroxine. Lancet 340:435-6,1992.

37. Wimalawansa, S.J . - Long- and short-term side effects and safety of calcitonin in man: A prospectivestudy. Calcif Tissue Int 52(2):90,1993. 